\title{
Seasonal diet selection of cattle grazing a montane riparian community
}

\author{
STEVEN G. EVANS, ANDREW J. PELSTER, WAYNE C. LEININGER, AND M. J. TRLICA
}

Authors are Natural Resource Specialist, 19 Mile Ranch, Uvalde, Tex. 78801; Natural Resource Specialist, City of Boulder Open Space and Mountain Parks Department, Boulder, Colo. 80301; and Professors, Forest, Rangeland and Watershed Stewardship, Colorado State University, Fort Collins, Colo. 80523.

Abstract

Cattle-grazing in riparian areas has become increasingly controversial. More information is needed about cattle use of these areas to develop Best Management Practices. This study was designed to determine seasonal changes in diet selection of cattle in a montane riparian community in northern Colorado. Previous cattle diet studies in riparian zones have not separated the interaction between seasonal preference and biomass utilization. The experiment was conducted within large exclosures that had not been grazed by livestock since 1956 . Vegetation biomass estimates and diet samples from 5 esophageally fistulated steers were taken during 4 grazing periods (spring, early-summer, latesummer, and fall) in 1995. Vegetation measurements and diet samples were also collected during the late summer and fall of 1994. One of the 3 paddocks in each grazing period of 1995 had been grazed in 1994. Steer diets in 1995 were found to contain $15 \%$ more Carex spp. from paddocks that had been ungrazed until 1995 as compared with paddocks previously grazed in 1994. Kentucky bluegrass (Poa pratensis L.) and forbs were consumed about 13 times and 5 times greater, respectively, in previously grazed paddocks as compared with ungrazed paddocks. Carex spp. were the most preferred component of cattle diets throughout the study. Willows (Salix spp.) were not preferred in any grazing period of either year, and consisted of less than $4 \%$ of cattle diets in any season. However, a trend towards increased consumption of willows was found from spring to fall, 1995. Information obtained in this study should help managers develop grazing systems that allow for a desirable combination of herbaceous and woody species in a riparian community while still affording grazeable forage.

Key Words: Steer diets, grazing management, diet composition, preference, utilization, Salix spp.

Management of domestic livestock on western riparian areas has become increasingly controversial (Chaney et al. 1993, Huber et al. 1995, Belsky et al. 1999). Heavy continuous grazing on these areas can have negative impacts on streambank stability (Platts 1981, Chaney et al. 1993, Belsky et al. 1999) and water quality (Platts 1979, Belsky et al. 1999, Trlica et al. 2000). It has been documented that excluding grazing on impacted riparian areas can improve their condition over time (Kauffman et al.

Research was funded by the USDA-CSREES Rangeland Research Grants Program and Colorado State University Agricultural Experiment Station.

Manuscript accepted 29 Feb. 04.
Resumen

El apacentamiento del ganado en áreas ribereñas se ha convertido en una controversia creciente. Se necesita más información acerca del uso de estas áreas por el ganado para desarrollare las Mejores Prácticas de Manejo. Este estudio se diseño para determinar los cambios estacionales en la selección de la dieta del ganado en una comunidad ribereña montañosa del norte de Colorado. Estudios previos sobre la dieta del ganado realizados en zonas ribereñas no han separado la interacción entre la preferencia estacional y la utilización de la biomasa. El experimento se condujo dentro de grandes exclusiones que no habían sido apacentadas por ganado desde 1956. Estimaciones de biomasa vegetal y muestras de la dieta de 5 novillos con fistula esofágica se tomaron durante 4 periodos de apacentamiento (primavera, inicios de verano, fines de verano y otoño) en 1995. Las mediciones de vegetación y las muestras de la dieta también fueron colectados a fines de verano y otoño de 1994. Uno de 3 potreros en cada periodo de apacentamiento de 1995 había sido apacentado en 1994. Se encontró que en 1995 las dietas de los novillos de los potreros que no habían sido apacentados hasta ese año contenían $15 \%$ más Carex spp. en comparación con los potreros previamente apacentados en 1994. El "Kentucky bluegrass" (Poa pratensis L.) y las hierbas fueron consumidas aproximadamente 13 y 5 veces más, respectivamente, en los potreros apacentados previamente en comparación con los potreros sin apacentar. A través del estudio las especies de Carex spp. fueron el componente más preferido de las dietas del ganado. Las especies de "Willows" (Salix spp.) no fueron preferidas en ningún periodo de apacentamiento de ningún año y en cualquier periodo de apacentamiento constituyeron menos del $4 \%$ de la dieta del ganado. Sin embargo, se encontró una tendencia a consumir mas "Willows" de primavera a otoño de 1995. La información obtenida en este estudio debe ayudar a los manejadores de pastizales a desarrollar sistemas de apacentamiento que permitan una comunidad ribereña deseable que combine especies herbáceas y leñosas y que pueda tener forraje consumible por el ganado.

1983a, 1983b); however, little information on diet preferences of cattle within the riparian communities could be found in the literature. This information is needed to develop Best Management Practices for maintenance or restoration of these areas for a desirable vegetation composition (Baker and Leininger 1992).

Cattle increase their utilization of browse in riparian areas as the growing season progresses (Holechek et al. 1982, Roath and Krueger 1982, Myers 1989). Cattle also increase browse utilization as available green herbage declines (Holechek et al. 1982, 
Kauffman et al. 1983b, Myers 1989 , Kovalchik and Elmore 1991). However, the above studies were not confined to only the riparian community and did not separate seasonal browse use from forage availability. This study was designed to determine seasonal diet preferences of cattle within an ungrazed montane riparian community, thus reducing the effect of forage availability as a factor in cattle diet selection (Loehle and Rittenhouse 1982). We hypothesized that cattle diet selection would shift from herbaceous species to willows (Salix spp.) as the growing season progressed.

\section{Materials and Methods}

\section{Study Area}

The study site was located $80 \mathrm{~km}$ northwest of Fort Collins, Colo. along Sheep Creek in the Roosevelt National Forest (Lat $40^{\circ} 56^{\prime} 70^{\prime \prime} \mathrm{N}, 105^{\circ} 40^{\prime} 18^{\prime \prime} \mathrm{W}$ ). This montane site is at an elevation of approximately $2500 \mathrm{~m}$. Sheep Creek is classified as a C3 stream according to Rosgen (1994). Common grasses found on the site included Kentucky bluegrass (Poa pratensis L.), fowl bluegrass ( $P$. palustris L.), bluejoint reedgrass (Calamagrostis canadensis Michx.), Timothy (Phleum pratense L.), and tufted hairgrass (Deschampsia caespitosa (L.) Beauv.). Water sedge (Carex aquatilis Wahl), beaked sedge (C. rostrata Stokes), small winged sedge (C. microptera Mack.), ovalhead sedge ( $C$. festivella Mack.), Nebraska sedge (C. nebraskensis Dewey), and Baltic rush (Juncus balticus Willd.) were the common grass-like species on the site. Several forb species and shrubby cinquefoil (Potentilla fruiticosa L.) were also common on the site (Schulz and Leininger 1990, Popolizio et al. 1994). The 2 most common species of the overstory included planeleaf willow (Salix planifolia Pursh) and Geyer's willow ( $S$. geyeriana Anders.), while peachleaf willow (S. amygdaloides Anderss), Wolf willow ( $S$. wolfii Bebb), sandbar willow ( $S$. exigua Nutt.), and yellow willow (S. lutea Nutt.) were other common willow species in the study area.

The study took place within 3 large grazing exclosures established along Sheep Creek in 1956 by the USDA Forest Service and the Colorado Division of Wildlife in an effort to protect and improve fish habitat (Stuber 1985). A total area of 40 ha in the riparian zone and $2.5 \mathrm{~km}$ of stream were fenced to exclude cattle.
Monthly precipitation and temperature at the study site were assumed to be similar to those recorded at the Red Feather Lakes weather station, approximately 15 $\mathrm{km}$ south of Sheep Creek. The average monthly precipitation at Red Feather Lakes for April through September of 1994 was about $65 \%$ of the 30 year average, and temperature was $1.2^{\circ} \mathrm{C}$ above normal for this period (Colorado Climate 1994). The interim period of October 1994 through March 1995 had $86 \%$ of average annual precipitation for that period. The months of April through September of 1995 had total precipitation that was about $170 \%$ above normal for this period, and temperatures for these same 6 months were $0.6^{\circ} \mathrm{C}$ below average (Colorado Climate 1995).

\section{Vegetation and Diet Sampling}

Fourteen paddocks of approximately 0.25 ha in size were randomly selected within 3 exclosures in the Sheep Creek riparian community and fenced. Each of these paddocks consisted of approximately $1 / 3$ willow and $2 / 3$ herbaceous vegetation cover. Six paddocks were sampled for forage availability and diet composition in 1994; 3 were sampled during the late-summer grazing period and 3 during the fall grazing period. Twelve paddocks were sampled for forage availability and diet composition throughout the growing season of 1995; 3 in each of the spring, earlysummer, late-summer, and fall grazing periods. The grazing periods corresponded to 4 different stages of phenological development of the willow species. These phenological stages were flowering and leaf emergence, rapid leaf expansion, mature leaf clusters, and leaf senescence. One of the paddocks within each grazing period of 1995 had been grazed previously in 1994 at a low level of utilization (approximately $25 \%$ ).

Forage availability was estimated for herbaceous vegetation using a double sampling technique (Bonham 1989). Weight for each vegetation class was ocularly estimated in forty, $0.25 \mathrm{~m}^{2}$ quadrats (4 transects of 10 quadrats each) within each paddock. Two quadrats along each transect were randomly selected and clipped to ground level to obtain a wet weight for each vegetation class. Available willow and other shrub biomass were estimated by clipping current year's growth from all shrubs that were rooted within any quadrat and were below a height of $2 \mathrm{~m}$ (the height to which willow biomass was available to steers). Carex spp., Salix spp., Calamagrostis canadensis, Deschampsia caespitosa, Poa pratensis, Juncus balticus, and forbs were the predominant vegetation classes found within the Sheep Creek riparian community. For the purpose of this study, vegetation class refers to any genus, species, or other group of vegetation included in the study (e.g. Carex spp., Poa pratensis, forbs). These classes collectively made up 80 to $100 \%$ of both cattle diet and available biomass during each period sampled. Clipped vegetation was oven-dried at $55^{\circ} \mathrm{C}$ for 72 hours to obtain dry weights. A linear regression of measured vs. ocular estimates of weights was developed to estimate weights for each vegetation class.

Cattle diet samples were collected using 5 esophageally fistulated Holstein steers. Steers were allowed to graze the riparian community in holding paddocks before, after, and between sampling periods in both 1994 and 1995, thus gaining experience in grazing the riparian area. Prior to each sampling period, steers were fasted through the night and then allowed to graze for several minutes within the paddock before samples were taken during their morning feeding event. Diet samples were taken in the morning and evening during the late-summer sampling period in 1994, but no differences $(P>0.10)$ were found between these 2 feeding events and sampling twice a day caused irritation of the fistula. Therefore, subsequent sampling was only conducted during the morning. Diets were sampled using 1 steer at a time. An adequate diet sample was obtained in a 20 min sampling period. Sampling times longer than 20 min resulted in excessive closure and irritation of the fistula opening. Samples were collected by use of a bag attached over the fistula opening of each steer. All sample material collected in the $20 \mathrm{~min}$ period was used for analysis. Diet samples were removed from the bag, rinsed with water, and placed on ice in the field. They were then taken to the laboratory where they were dried at $55^{\circ} \mathrm{C}$ and ground through a $1 \mathrm{~mm}$ mesh screen. Sub-samples were then placed on microscope slides, and percentage composition by vegetation class was determined using the micro-histological technique of Sparks and Malechek (1968). Three slides were prepared and analyzed for each diet sample. Twenty grid points were read for each slide to determine percentage composition of vegetation classes found within each sample.

A relative preference index (RPI) was determined for each of the 7 dominant vegetation classes. This index was calculated for each of the 6 grazing periods and 
followed Ivlev's (1961) formula. Non-preferred food items have an index value between -1 and 0 , and preferred items have values between 0 and +1 .

\section{Data Analysis}

Data were analyzed to determine if differences existed in biomass $(\mathrm{kg} / \mathrm{ha})$ and diet composition (\%) of individual vegetation classes among ungrazed and previously grazed paddocks. Grazing period and replicate were both fixed effects. A contrast statement was used to compare data from those ungrazed paddocks sampled in 1995 with data from other paddocks sampled in 1995 that had been previously grazed in 1994. Computations were performed using SAS Proc GLM (SAS 1988).

Further analyses were used to test for differences in standing crop of aboveground biomass and differences in composition of diets, by vegetation class, among grazing periods and between the 2 years of the study. A mixed model ANOVA (Steel and Torrie 1980) was computed using PROC MIXED in SAS (SAS 1988). In this analysis, biomass $(\mathrm{kg} / \mathrm{ha})$ and composition (\%) of diet were the response variables. To make error variance more homogeneous, percentages were transformed by taking the arcsin square root of the diet values before statistical analyses (Sokal and Rohlf 1981). Replicate was a random effect nested within grazing period, which was a fixed effect. The 2 years were compared using a contrast of grazing periods. An alpha level of 0.10 was used to test for significance within all analyses.

\section{Results and Discussion}

\section{Biomass}

Standing crop of aboveground biomass for the late-summer and fall periods of 1994 was approximately $4300 \mathrm{~kg} / \mathrm{ha}$, while standing crop for the same 2 periods in 1995 averaged approximately $30 \%$ less (Fig. 1). Aboveground biomass in 1995 increased in a linear manner in response to the length of time that plants had been growing (Fig. 1). Greater biomass production in 1994, as compared with 1995 , probably resulted from the longer and warmer growing season experienced in 1994. The 1995 growing season was delayed, with cool temperatures and higher than average precipitation early in the growing season. This may have caused a decrease in aboveground biomass production later in the 1995 growing season. Saturated soils warm slowly, resulting in a reduction of microbial activity and root

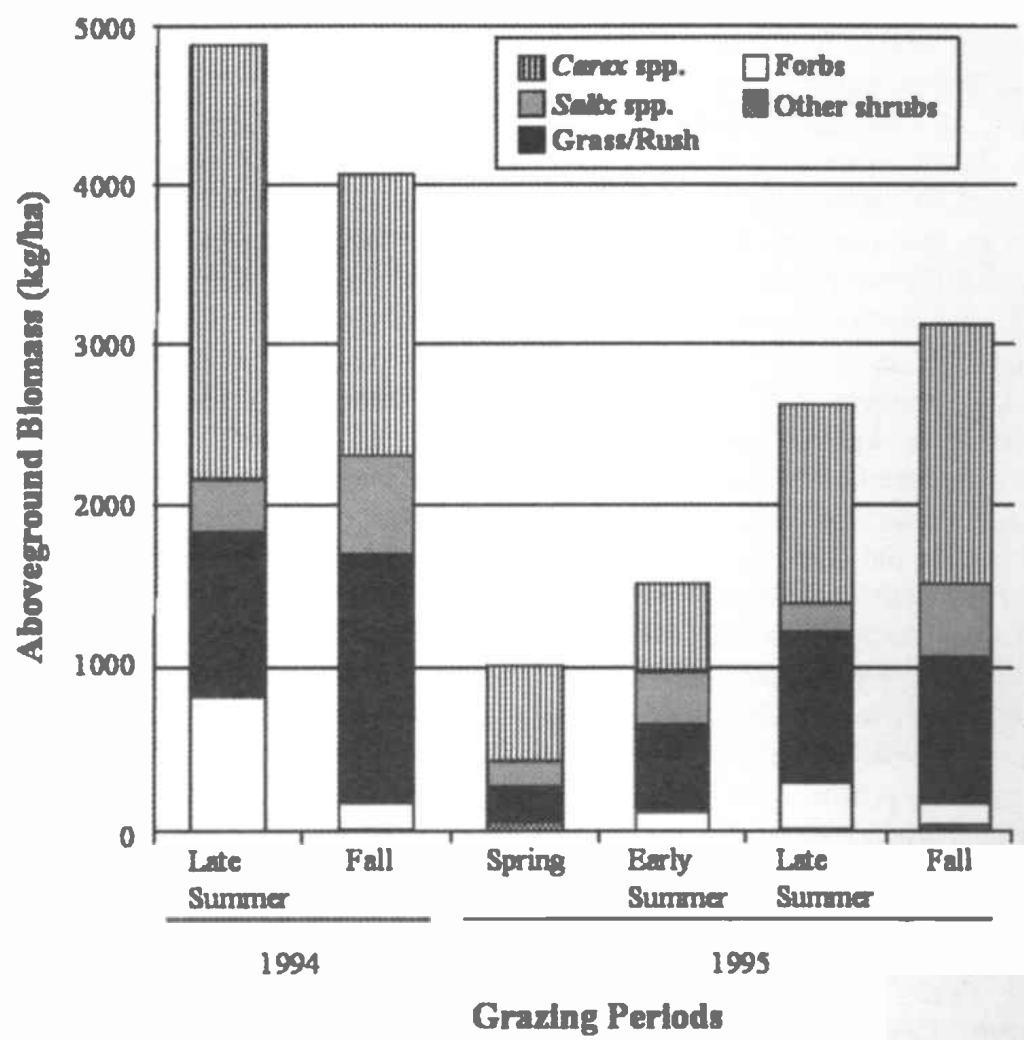

Fig. 1. Available biomass by vegetation class for 2 grazing periods in 1994 and 4 grazing periods in 1995 for a montane riparian community.

growth, thus causing a reduction of nutrient uptake (Buckman and Brady 1969). Aboveground biomass estimates for both years of the study were comparable with previous biomass estimates for the Sheep Creek riparian area reported by Schulz and Leininger (1990). These biomass values were also similar to those reported in other riparian studies in Oregon (Kauffman et al. 1983b) and California (Huber et al. 1995).

When aboveground biomass for the various vegetation classes in 1995 were compared for the previously grazed (i.e., 1994) and ungrazed paddocks, 3 vegetation classes were found to have differences in biomass. Grasses and rushes produced $38 \%$ more $(\mathrm{P}<0.10)$ biomass in ungrazed paddocks than in previously grazed paddocks. Calamagrostis canadensis was the only single species that showed a response to grazing; ungrazed paddocks averaged 329 $\mathrm{kg} / \mathrm{ha}$ more biomass $(\mathrm{P}<0.10)$ than was found in previously grazed paddocks. In contrast, aboveground biomass of forbs averaged $52 \mathrm{~kg} / \mathrm{ha}$ less $(\mathrm{P}<0.01)$ in ungrazed paddocks than in previously grazed paddocks. Huber et al. (1995) reported greater total biomass production in previously grazed riparian pastures than in ungrazed pastures in California.

Two classes of vegetation showed significant responses when compared among all grazing periods. Carex spp. differed $(\mathrm{P}$
$<0.10$ ) in the amount of aboveground biomass produced seasonally. Carex spp. had low biomass production $(590 \mathrm{~kg} / \mathrm{ha})$ in the spring of 1995 and highest aboveground biomass in the late-summer 1994 (2693 $\mathrm{kg} / \mathrm{ha}$ ). Additionally, biomass in late-summer of 1994 was twice that of late-summer $1995(\mathrm{P}<0.10)$. The group of grasses and rushes differed $(P<0.10)$ seasonally in aboveground biomass when this vegetation class was compared across all grazing periods. In the spring of $1995,194 \mathrm{~kg} / \mathrm{ha}$ was produced compared to $1495 \mathrm{~kg} / \mathrm{ha}$ in the fall of 1994.

Deschampsia caespitosa was also found to differ $(P<0.10)$ in aboveground biomass when all grazing periods of the study were compared. Greatest aboveground biomass for $D$. caespitosa, at $254 \mathrm{~kg} / \mathrm{ha}$, was found in late summer of 1994 , while only $1.2 \mathrm{~kg} / \mathrm{ha}$ of aboveground biomass was found in the late-summer 1995. There also was a difference $(\mathrm{P}<0.01)$ in biomass when the late-summer grazing periods of 1994 and 1995 were compared. Aboveground biomass of $D$. caespitosa in late-summer 1994 was 2.5 times greater than that of late-summer 1995. Also, $D$. caespitosa biomass was greater $(\mathrm{P}<0.05)$ in 1994 than in 1995, and greater $(\mathrm{P}<$ 0.10 ) in the combined late-summer grazing periods than in the combined fall grazing periods. These differences likely 
resulted from the much greater amounts of $D$. caespitosa found in those paddocks sampled in late-summer 1994 compared with other paddocks sampled throughout the study. Poa pratensis had 6.7 times greater $(P<0.10)$ biomass in late-summer 1994 than in late-summer 1995. Juncus balticus also differed $(\mathrm{P}<0.10)$ seasonally in aboveground biomass when all grazing periods of the study were compared. Aboveground biomass was lowest in the spring of 1995 (42 kg/ha) and the greatest in the late summer of 1994 (947 kg/ha). In addition, J. balticus had $89 \%$ greater $(\mathrm{P}<$ $0.01)$ biomass in the late-summer grazing period of 1994 than in the same period in 1995; 5 times greater $(P<0.01)$ biomass in the 2 combined grazing periods of 1994 than in 1995; and over 6 times greater $(\mathrm{P}<$ 0.01 ) aboveground biomass in the latesummer grazing period than in the fall grazing period when averaged across both years of the study. Forbs differed $(\mathrm{P}<$ 0.05 ) seasonally in aboveground biomass when all grazing periods of the study were compared. Forbs had only $13 \mathrm{~kg} / \mathrm{ha}$ of aboveground biomass in spring, 1995 compared to $301 \mathrm{~kg} / \mathrm{ha}$ in the late-summer, 1994. Forbs also had 13\% more ( $P<0.10)$ biomass in the late-summer of 1994 than in the late-summer of 1995 . No other biomass differences were found seasonally or between common grazing periods during the 2 years of the study.

\section{Cattle Diets}

There were significant differences in steer diets between previously grazed and ungrazed paddocks for 5 vegetation classes (data not shown). Carex spp. made up a smaller $(P<0.01)$ proportion of steer diets in the grazed paddocks in 1995 compared with those that were ungrazed in 1994 $(68 \%$ of steer diets in the grazed paddocks compared to $85 \%$ of diets in the ungrazed paddocks). In contrast, Calamágrostis canadensis, Deschampsia caespitosa, Poa pratensis, and forbs were all consumed in higher $(\mathrm{P}<0.10)$ proportions in those previously grazed paddocks than in the ungrazed paddocks. The composition of $C$. canadensis in steer diets averaged $4 \%$ in the previously grazed paddocks, compared to only $2.5 \%$ in ungrazed paddocks. The greater proportion of $C$. canadensis in steer diets from previously grazed paddocks likely resulted from the greater amount of biomass of $C$. canadensis in previously grazed than in ungrazed paddocks. Steer diets contained slightly more $(\mathrm{P}<0.01)$ D. caespitosa from the previously grazed paddocks compared with ungrazed paddocks. The proportion of $P$. pratensis and forbs in steer diets from previously grazed paddocks was 13 ( $\mathrm{P}<$ $0.01)$ and 5 times $(P<0.01)$, respectively, the proportion in ungrazed paddocks. This might have been caused by greater biomass production of forbs in previously grazed paddocks, and the increased visibility of forbs to steers in those paddocks. Other explanations that could account for the differences in consumption were probably differences in forage quality or availability. In another study conducted at Sheep Creek, forage quality was found to be higher in previously grazed paddocks than in ungrazed paddocks (Phillips et al. 1999). Additionally, it appeared that the litter layer was reduced on previously grazed paddocks possibly making availability of these vegetation classes greater to the steers. Greater consumption of these other vegetation classes by steers in previously grazed paddocks probably caused a reduction in intake of Carex spp. in those paddocks. There were no significant differences $(P>0.10)$ in the utilization of Juncus balticus, grasses and rushes, or Salix spp. between previously grazed and ungrazed paddocks.

No differences $(P>0.10)$ were found within vegetation classes when seasonal differences among all grazing periods for both years were compared. Diet analyses where the grazing periods of late-summer and fall that were common to both years showed differences in diet composition for only forbs and Deschampsia caespitosa. Steers consumed a greater $(P<0.10)$ percentage of forbs in late-summer than in fall when averaged across both years of the study. This probably resulted from the greater standing crop of forbs in the latesummer grazing period than in the fall, and possibly differences in relative palatability of forbs between these 2 periods. A study by Neel et al. (1991) showed that forbs were a major year-round component of cattle diets in a riparian community in
New Mexico. Consumption of D. caespitosa was greater $(\mathrm{P}<0.05)$ in the latesummer and fall of 1994 than in the latesummer and fall of 1995 . This might be explained by the greater aboveground biomass of $D$. caespitos $a$ in those paddocks sampled in 1994, as compared with biomass in those paddocks sampled in the late-summer and fall of 1995.

\section{Relative Preference}

The relative preference indices developed for the vegetation classes found at the Sheep Creek study site revealed that Carex spp. were preferred (larger positive values) in both ungrazed paddocks and those previously grazed in 1994 (Table 1). Salix spp., Poa pratensis, Calamagrostis canadensis, Deschampsia caespitosa, forbs, and the combined vegetation class of grasses and rushes were all non-preferred classes in both previously grazed and ungrazed paddocks. Juncus balticus was not preferred in the ungrazed paddocks while steers showed a neutral preference for $J$. balticus in the previously grazed paddocks. Forbs were less preferred in ungrazed paddocks compared with previously grazed paddocks.

Relative preference indices calculated for vegetation classes for all grazing periods of the study indicated that Carex spp. were preferred in all periods of the study, except late-summer 1995 when preference for this species was neutral (Table 2). Salix spp. were avoided in all grazing periods of the study. Similarly, Poa pratensis was not preferred in any of the grazing periods of the study. Juncus balticus was avoided during late-summer of 1994 and the late-summer and fall of 1995. However, neutral preference for this species was exhibited in fall, 1994 and spring and early-summer of 1995. Steers did not prefer Calamagrostis canadensis during any grazing period of the study. Steers demonstrated a neutral preference

Table 1. Relative preference indices (mean $\pm \mathrm{SE}$ ) of steers for dominant vegetation classes at the Sheep Creek study area, 1994 and 1995. Indices followed Ivlev's (1961) formula and were used to compare previously grazed with ungrazed paddocks.

\begin{tabular}{lcc}
\hline \hline Vegetation Classes & Previously Grazed $^{1}$ & Ungrazed $^{-1}$ \\
\hline Carex spp. & $.14 \pm .11^{2}$ & $.28 \pm .03$ \\
Salix spp. & $-.86 \pm .06$ & $-.74 \pm .07$ \\
Poa pratensis & $-.55 \pm .12$ & $-.66 \pm .08$ \\
Juncus balticus & $-.14 \pm .17$ & $-.31 \pm .12$ \\
Calamagrostis canadensis & $-.79 \pm .08$ & $-.54 \pm .09$ \\
Deschampsia caespitosa & $-.78 \pm .16$ & $-.68 \pm .13$ \\
Forbs & $-.45 \pm .14$ & $-.70 \pm .08$ \\
Grasses/Rushes & $-.58 \pm .10$ & $-.53 \pm .07$ \\
\hline
\end{tabular}

Previously grazed paddocks $=$ those grazed to approximately $40 \%$ utilization during the late-summer or fall of the previous growing season. Ungrazed paddocks $=$ those that were excluded from domestic livestock grazing for 38 years.

${ }^{2}$ Standard error of the mean. 
Table 2. Relative preference indices (mean $\pm \mathrm{SE})^{1}$ of steers for dominant vegetation classes at the Sheep Creek study area, 1994 and 1995 . Indices followed Ivlev's (1961) formula.

\begin{tabular}{|c|c|c|c|c|c|c|}
\hline Vegetation Classes & $\begin{array}{l}\text { Late-Summer } \\
1994\end{array}$ & $\begin{array}{l}\text { Fall } \\
1994\end{array}$ & $\begin{array}{l}\text { Spring } \\
1995\end{array}$ & $\begin{array}{c}\text { Early-Summer } \\
1995\end{array}$ & $\begin{array}{l}\text { Late Summer } \\
1995\end{array}$ & $\begin{array}{c}\text { Fall } \\
1995\end{array}$ \\
\hline $\begin{array}{l}\text { Carex spp. } \\
\text { Salix spp. } \\
\text { Poa pratensis } \\
\text { Juncus.balticus } \\
\text { Calamagrostis canadensis } \\
\text { Deschampsia caespitosa } \\
\text { Forbs } \\
\text { Grasses/Rushes }\end{array}$ & $\begin{array}{r}.22 \pm .05 \\
-.67 \pm .10 \\
-.60 \pm .10 \\
-.25 \pm .14 \\
.18 \pm .24 \\
-.59 \pm .09 \\
-.33 \pm .10\end{array}$ & $\begin{array}{r}.28 \pm .06 \\
-.88 \pm .06 \\
-.20 \pm .16 \\
-.05 \pm .19 \\
-.61 \pm .10 \\
.18 \pm .20 \\
-.68 \pm .11 \\
-.32 \pm .11\end{array}$ & $\begin{array}{r}.13 \pm .06 \\
-.90 \pm .05 \\
-.57 \pm .13 \\
-.16 \pm .23 \\
-.54 \pm .10 \\
-.11 \pm .33 \\
-.76 \pm .09 \\
-.48 \pm .11\end{array}$ & $\begin{array}{r}.33 \pm .06 \\
-.88 \pm .04 \\
-.85 \pm .06 \\
.16 \pm .17 \\
-.90 \pm .04 \\
-.65 \pm .21 \\
-.73 \pm .06 \\
-.54 \pm .12\end{array}$ & $\begin{array}{r}.05 \pm .11 \\
-.65 \pm .14 \\
-.25 \pm .13 \\
-.59 \pm .13 \\
-.80 \pm .07 \\
-.65 \pm .31 \\
-.02 \pm .19 \\
-.62 \pm .08\end{array}$ & $\begin{array}{r}.25 \pm .04 \\
-.61 \pm .14 \\
-.97 \pm .02 \\
-.19 \pm .16 \\
-.63 \pm .11 \\
-.67 \pm .22 \\
-.67 \pm .12 \\
-.51 \pm .14\end{array}$ \\
\hline
\end{tabular}

'Standard error of the mean

for Deschampsia caespitosa during the late-summer and fall 1994 and spring 1995 and D. caespitosa was avoided during the early summer, late-summer, and fall of 1995. Forbs were avoided during all grazing periods of the study, except during the late-summer of 1995 when steers demonstrated a neutral preference for them. As a group, grasses and rushes were not preferred by the steers throughout the study.

\section{Diet and Available Biomass}

Carex spp. made up the majority of the composition of steer diets throughout all grazing periods of this study (Table 3 ). Carex spp. made up a higher percentage of steer diets than was available on offer when averaged across all grazing periods of both 1994 and 1995 (Table 4). Steer diets consisted of between 65 and $85 \%$ Carex spp. while this class was between 38 and $61 \%$ of the forage available to the steers (Table 3). Huber et al. (1995) stated that Carex spp. and Juncus balticus were the 2 most predominant components in cattle diets from riparian areas during midsummer. Kauffman et al. (1983b) observed that Carex spp. were utilized between $65-81 \%$ during late-season grazing in a riparian community in eastern Oregon. Consumption of Carex spp. may remain high late in the grazing season because they typically maintain high levels of crude protein until the first killing frost. Additionally, many Carex spp. in the Pacific Northwest retain protein levels longer into the growing season than upland forage species (McLean et al. 1963, Paulsen 1969, Skovlin 1967, Kauffman and Krueger 1984). Based on the results of this present study and that of Pelster et al. (2004), Carex spp. could be used by managers as a key species when monitoring utilization of riparian communities.

In contrast to Carex spp., Salix spp. were only about $15 \%$ as common in the diet of steers as they were in the forage available for grazing when averaged across all grazing periods of the study (Table 4). Salix spp. made up between 1 and $4 \%$ of steer diets throughout the study, while available biomass was between 7 and $45 \%$ (Table 3 ). An interesting trend towards an increase of Salix spp. in steer diets was apparent in 1995 (Fig. 1). These findings generally agree with Huber et al. (1995) who noted that Salix spp. made up $0.1 \%$ or less of steer diets in a riparian community in California from June 5 through August 1. Results from our study generally agree with Kauffman et al. (1983b) who observed that shrub use by cattle in Oregon was more closely related to availability of herbaceous vegetation and shrub species than to season of use. They noted that as long as there was available herbaceous vegetation within the riparian community, utilization of shrubs during late-season grazing was minimal.

Poa pratensis was about 2.3 times as common in the composition of biomass that was available than it was in the diet of steers when averaged across all grazing periods of the study (Table 4). P. pratensis ranged from less than 1 to $5.5 \%$ of cattle diets throughout the study and from 4.5 to $9.2 \%$ of available biomass (Table 3 ). Kauffman et al. (1983b) found that utilization of $P$. pratensis could be as high as 55 to $80 \%$ in riparian meadows, whereas this grass was utilized much less in the present study. This may be related to the greater composition of sedges and rushes available in our study.

Juncus balticus was approximately 1.5 times more common in the diets of steers than was available for consumption when averaged across all grazing periods of 1994 and 1995 (Table 4). J. balticus made up from 2 to $14 \%$ of steers' diets, and 2.2 to $5.5 \%$ of available biomass, throughout the study. Kauffman et al. (1983b) reported that cattle grazed J. balticus to a $30 \%$ utilization level in late-summer in a moist meadow community in Oregon.

Calamagrostis canadensis comprised 5 times the amount of the biomass available

Table 3. Available biomass (\%) and diet (\%) of steers for dominant vegetation classes at the Sheep Creek study area, 1994 and 1995.

\begin{tabular}{|c|c|c|c|c|c|c|c|c|c|c|c|c|}
\hline \multirow[b]{3}{*}{ Vegetation Classes } & \multicolumn{4}{|c|}{1994} & \multicolumn{8}{|c|}{1995} \\
\hline & \multicolumn{2}{|c|}{ Late-Summer } & \multicolumn{2}{|c|}{ Fall } & \multicolumn{2}{|c|}{ Spring } & \multicolumn{2}{|c|}{ Early-Summer } & \multicolumn{2}{|c|}{ Late-Summer } & \multicolumn{2}{|c|}{ Fall } \\
\hline & Biomass & Diet & Biomass & Diet & Biomass & Diet & Biomass & Diet & Biomass & Diet & Biomass & Diet \\
\hline Carex spp. & 53.6 & 74.9 & 46.5 & 76.7 & 61.2 & 85.4 & 37.9 & 79.9 & 45.2 & 66.8 & 51.9 & 85.2 \\
\hline Salix spp. & 7.3 & 1.5 & 12.9 & 1.1 & 14.3 & 1.1 & 18.7 & 1.9 & 45.2 & $\begin{array}{r}2.5 \\
\end{array}$ & 15.1 & $\begin{array}{r}0.5 \\
3.7\end{array}$ \\
\hline Forbs & 17.0 & 6.4 & 6.0 & 1.0 & 1.2 & 1.0 & 7.2 & 1.9 & 10.1 & 18.4 & 4.1 & 3.7 \\
\hline Grasses/Rushes & 21.9 & 16.0 & 34.4 & 19.8 & 19.7 & 12.3 & 35.9 & 16.1 & 37.0 & 10.7 & 28.2 & 8.8 \\
\hline Poa pratensis & 4.7 & 2.0 & 9.2 & 4.9 & 5.3 & 5.5 & 6.7 & 0.7 & 5.1 & 3.7 & 9.2 & 0.9 \\
\hline Juncus balticus & 5.6 & 8.5 & 2.2 & 5.4 & 2.8 & 1.9 & 5.5 & 14.2 & 4.3 & 2.0 & 2.8 & 3.1 \\
\hline $\begin{array}{l}\text { Calamagrostis } \\
\text { canadensis } \\
\text { Deschampsia }\end{array}$ & 0.0 & 1.8 & 10.4 & 5.2 & 6.9 & 3.1 & 20.5 & 1.4 & 23.5 & 3.8 & 15.4 & 3.4 \\
\hline caespitosa & 0.5 & 1.7 & 0.5 & 1.8 & 0.8 & 0.9 & 0.2 & 0.2 & 0.0 & 0.1 & 0.2 & 0.4 \\
\hline
\end{tabular}


Table 4. Percentage composition ( \pm 1 S.E.) of available plant biomass and steer diets at the Sheep Creek study area averaged across grazing periods that were sampled in 1994 and 1995.

\begin{tabular}{|c|c|c|}
\hline Vegetation Classes & Available Biomass & Diet \\
\hline & \multicolumn{2}{|c|}{ 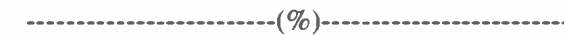 } \\
\hline Carex spp. & $49.4 \pm 3.7$ & $78.2 \pm 2.8$ \\
\hline Salix spp. & $12.6 \pm 1.8$ & $2.0 \pm 0.4$ \\
\hline Poa pratensis & $6.7 \pm 0.8$ & $2.9 \pm 0.8$ \\
\hline Juncus balticus & $3.8 \pm 0.6$ & $5.8 \pm 2.0$ \\
\hline Calamagrostis canadensis & $15.3 \pm 2.8$ & $3.1 \pm 0.6$ \\
\hline Deschampsia caespitosa & $0.3 \pm 0.1$ & $0.8 \pm 0.3$ \\
\hline Forbs & $7.6 \pm 2.2$ & $5.4 \pm 2.7$ \\
\hline Grasses/Rushes & $29.3 \pm 3.0$ & $13.9 \pm 1.7$ \\
\hline
\end{tabular}

to steers compared to that found in steers' diets when averaged across the study (Table 4). C. canadensis ranged from 2 to $5 \%$ of steer diets throughout the study, and from 7 to $23 \%$ of available forage. Deschampsia caespitosa was found in greater percentages in the diets of steers than in the relative biomass available to them when averaged across all grazing periods. However, D. caespitosa never made up more than $2 \%$ of either diet or available biomass throughout the study (Table 3 ). Forbs were only about $70 \%$ as abundant in the diet as they were available to the steers when averaged across all grazing periods of 1994 and 1995 (Table 4). Forbs ranged from 1 to $18 \%$ of steers' diets, and 1 to $17 \%$ of available forage, throughout the study (Table 3 ). Combined grasses and rushes were found to be less in the steer's diets than in the available forage throughout the study (Table 4). Combined grasses and rushes ranged from about $8 \%$ to $20 \%$ of cattle diets throughout the study, while available forage ranged from 20 to $37 \%$.

\section{Conclusions}

Results of this study support findings from some studies for cattle diets within riparian areas, but contradict others. Previous diet studies (Holechek et al. 1982, Roath and Krueger 1982, Myers 1989) have indicated increased browse consumption in riparian areas late in the growing season, citing increased maturity and decreased palatability of the herbaceous vegetation as possible reasons. However, these previous studies did not separate the interaction between grazing season and level of biomass removal. This present study showed that willows were strongly avoided throughout the entire growing season and never made up more than $4 \%$ of steer diets on riparian areas that had not been previously grazed during that year. However, a second study
(Pelster et al. 2004) conducted in conjunction with this present one showed that steers more readily consumed willow in late-summer and fall compared to earlier in the grazing season if stubble heights of herbaceous species had been reduced by grazing.

By knowing cattle preferences throughout an entire growing season, managers can use this information to make decisions such as when to place animals on, or remove animals from, riparian pastures. This present study indicated that cattle diets were generally very similar no matter what time of the growing season the animals grazed the riparian community. Carex spp. made up the majority of the available biomass consumed by cattle throughout this present study, while Salix spp., Calamagrostis canadensis, Deschampsia caespitosa, Poa pratensis, Juncus balticus, and forbs collectively made up the rest of the diet. Additionally, preference shown by steers towards Salix spp. did not change significantly throughout the growing season if herbaceous forage was abundant. This study showed no indication that steer diet selection was strongly influenced throughout the growing season by such factors as changes in vegetation chemistry (secondary compounds), quality, or palatability of forage.

Finally, there were observations made throughout this present study that could lead to additional future riparian studies. These studies might better explain the processes that occur within these unique areas. Native ungulates, elk and mule deer, were observed feeding on the regrowth in areas that had been previously grazed by cattle earlier in the growing season. Wildlife are known to prefer these areas after cattle have previously grazed them. Phillips et al. (1999) found that forage from paddocks grazed the previous year was higher in nitrogen and more digestible than forage from ungrazed paddocks. A study designed to examine which factors may influence cattle diet selection between previously grazed and ungrazed riparian communities may give managers better information in the design of grazing plans for riparian communities. Results of these studies could help managers understand how cattle grazing affects wildlife forage within a riparian zone, and what differences in diet might be expected when cattle are grazed on areas that have been rested as compared with those grazed annually.

\section{Literature Cited}

Baker, B.W. and W.C. Leininger. 1992. Research needs for riparian management. pp. 122-132. In. Proc. Colorado Riparian Assoc. Fourth Ann. Conv., Nov. 4-6, 1992,Steamboat Springs, Colo.

Belsky, A.J., A. Matzke, and S. Uselman. 1999. Survey of livestock influences on stream and riparian ecosystems in the western United States. J. Soil Water Cons. 54:419-431.

Bonham, C.D. 1989. Measurement of Terrestrial Vegetation. John Wiley \& Sons, Inc., New York, N.Y.

Buckman, H.O. and N.C. Brady. 1969. The Nature and Properties of Soils. Seventh Edition. The Macmillan Co., New York, N.Y.

Chaney, E., W. Elmore, and W.S. Platts. 1993. Managing change: Livestock grazing on western riparian areas. Northwest Resource Information Center, Eagle, Ida.

Colorado Climate, April-September. 1994. Colorado Climate Center. Dept. of Atmospheric Science. Colorado State University. Fort Collins. Vol. 17, No. 7 Vol. 17, No. 12

Colorado Climate, March-September. 1995. Colorado Climate Center. Dept. of Atmospheric Science. Colorado State University, Fort Collins. Vol. 18, No. 6 Vol. 18, No. 12

Holechek, J.L., M. Vavra, J. Skovlin, and W.C. Krueger. 1982. Cattle diets in the Blue Mountains of Oregon. II. Forests. J. Range Manage. 35:239-242.

Huber, S.A., M.B. Judkins, L.J. Krysl, T.J. Svejcar, B.W. Hess, and D.W. Holcombe. 1995. Cattle grazing a riparian mountain meadow: Effects of low and moderate stocking density on nutrition, behavior, diet selection, and plant growth response. J. Anim. Sci. 73:3752-3765.

Ivlev, V.S. 1961. Experimental Ecology of the Feeding of Fishes. Yale University Press, New Haven, Conn.

Kauffman, J.B. and W.C. Krueger. 1984. Livestock impacts on riparian ecosystems and streamside management implications: A review. J. Range Manage. 37:430-438.

Kauffman, J.B., W.C. Krueger, and M. Vavra. 1983a. Impacts of cattle on streambanks in northeastern Oregon. J. Range Manage. 36:683-685.

Kauffman, J.B., W.C. Krueger, and M. Vavra. 1983b. Effects of late season cattle grazing on riparian plant communities. J. Range Manage. 36:685-691. 
Kovalchik, B.L. and W. Elmore. 1991. Effects of cattle grazing systems on willowdominated plant associations in central Oregon. pp. 111-119. In. Proc. of the Symposium on Ecology and Management of Riparian Shrub Communities. USDA For. Serv. Gen. Tech. Rep. INT-289.

Loehle, C. and L.R. Rittenhouse. 1982. An analysis of forage preference indices. J. Range Manage. 35:316-319.

McLean, A., H.H. Nicholson, and A.L. Van Ryswyk. 1963. Growth productivity and chemical composition of a sub alpine meadow in interior British Columbia. J. Range Manage. 16:235-240.

Myers, L.H. 1989. Grazing and riparian management in southwestern Montana. pp. 117-120. In: Practical Approaches to Riparian Resource Management-An Educational Workshop. May 8-11, 1989, Billings, Mont. BLM-MT-PT-89-001-4351.

Neel, J.P., D.M. Manzanares, H.E. Kiesling, J.L. Holechek, and G.B. Donart. 1991. Cattle diets on riparian and upland New Mexico pinyon-juniper range. New Mex. J. Sci. 31:7-19.

Paulsen, H.A. Jr. 1969. Forage value on a mountain grassland aspen range in western Colorado. J. Range Manage. 22:102-107.
Pelster, A.J., S.G. Evans, W.C. Leininger, W.P.Clary, and M.J. Trlica. 2004. Steer diets in a montane riparian community. $\mathrm{J}$. Range Manage. 57:546-552.

Phillips, R., M.J. Trlica, W.C. Leininger, and W.P. Clary. 1999. Cattle use affects forage quality in a montane riparian ecosystem. J. Range Manage. 52:283-289.

Platts, W.S. 1979. Livestock grazing and riparian/stream ecosystems. pp. 39-45. In. Proc. Forum-Grazing and Riparian/Stream Ecosystem. Trout Unlimited Inc.

Platts, W.S. 1981. Influence of forest and rangeland management of anadromous fish habitat in western North America: Effects of livestock grazing. USDA For. Ser. Gen. Tech. Rep. PNW-124.

Popolizio, C.A., H. Goetz, and P.L.Chapman. 1994. Short-term response of riparian vegetation to 4 grazing treatments. J. Range Manage. 47:48-53.

Roath, L.R. and W.C. Krueger. 1982. Cattle influence on a mountain riparian zone. J. Range Manage. 35:100-104.

Rosgen, D.L. 1994. A classification of natural rivers. Catena 22:169-199.

SAS 1988. SAS/STAT User's guide. SAS Institute Inc., Cary, N.C.
Schulz, T.T. and W.C. Leininger. 1990. Differences in riparian vegetation structure between grazed areas and exclosure. J. Range Manage. 43:295-299.

Skovlin, J. 1967. Fluctuations in forage quality on summer range in the Blue Mountains. USDA Forest Serv. PNW-Res. Paper. 44.

Sokal, R.R. and F.J. Rohlf. 1981. Biometry. W.H. Freeman and Co., San Francisco, Calif

Sparks, D.R. and J.C. Malechek. 1968. Estimating percentage dry weights in diets using a microscopic technique. J. Range Manage. 21:264-265.

Steel, R.G.D. and J.H. Torrie. 1980. Principles and Procedures of Statistics: A Biometrical Approach. McGraw-Hill Book Co., New York, N.Y.

Stuber, R.J. 1985. Trout habitat, abundance, and fishing opportunities in fenced vs. protected riparian habitat along Sheep Creek, Colorado. pp. 310-314. In. Riparian Ecosystems and Their Management: Reconciling Conflicting Uses. USDA For. Ser. Gen. Tech. Rep. RM-120.

Trlica, M.J., E.A. Nibarger, W.C. Leininger and G.W. Frasier. 2000. Runoff water quality from grazed and ungrazed riparian plots. pp. 699-701. In. P.J. Wiginngton, Jr. (ed.) Proc. AWRA International Conf. on Riparian Ecology and Management in Multi-land Use Watersheds. Portland, Ore. 